\title{
PENGEMBANGAN GERAKAN GO GREEN DI SEKOLAH \\ DALAM MENINGKATKAN NASIONALISME \\ (Studi Di SMP Negeri 2 Dawuan Kabupaten Subang)
}

\section{Ridwan Lesmana}

\begin{abstract}
Environmental problem sarieas a result of human activity itself, from time to time a threat to Increasing environmental damage. Society has not shown aware nessin maintaining and managing the real environment.Many various illegal logging, exploitation of natural resources, littering, waste management out of control, are the kinds of actions that pollute and damage the environment. Looking at this, it is important and urgent agenda to do is build a culture of Go Green in every spheres of life. Forthat purpose, the schoolas an educational institution, can bein seminated and rooting media valuesbased culture of clean living environment that is useful for individuasl and public life learners. Schools must develop order and social-pedagogical culture that is conducive to the growth of a variety of personal qualities loving environment. The findings of this study are: (1) the behavior of learners in the development of the Go Green movement can boost nationalism, (2) the existence of barriers and obstacles in the development and implementation of the Go Green at the school, (3) Go Green movement prospects to the school, community and environment. The study recommends to stakeholders SMPN 2 Dawuan Subang to reinforce the perception of the Go Green movement, and the creation of school cultures that manifest Go Green environmentally friendly school with discipline frame so that learner sincreased nationalism.
\end{abstract}

Keyword : Go Green School, Nationalism

\section{A. Pendahuluan}

Pemanasan global yang terjadi sekarang ini merupakan ancaman bagi seluruh penduduk dunia sebagai akibat dari peningkatan konsentrasi zat rumah kaca di atmosfer karena aktivitas manusia seperti pembakaran BBM dan penebangan liar yang secara terus menerus terjadi hampir di seluruh wilayah dunia, meningkatnya polusi dan penipisan daya dukung sumber daya alam juga akibat dari aktivitas manusia dalam bidang industri, komersial dan pribadi.

Dengan kondisi tersebut memunculkan berbagai 
permasalahan yang berkaitan dengan masalah lingkungan, dimana tingkat kerusakan lingkungan semakin hari semakin parah serta mengancam kehidupan manusia, pembukaan lahan baru mengakibatkan banyaknya hutan yang dirusak karena umumnya pembukaan lahan tersebut tidak mengikuti kaidah ekologi. Rusaknya hutan akan merusak ekosistem yang ada dihutan tersebut dan lingkungan disekitarnya serta akan merusak semua sistem kehidupan di setiap komponen yang ada di bumi ini.

Untuk mengatasi hal tersebut upaya peletarian lingkungan hidup merupakan suatu kebutuhan yang tidak bisa ditunda lagi dan harus segera dilaksanakan dan bukan tanggung jawab dari pemerintah saja melainkan tanggung jawab seluruh warga masyarakat. Setiap orang harus melakukan usaha untuk menyelamatkan lingkungan hidup di sekitar kita sesuai kemampuan dan kapasitasnya masing-masing. Sekecil apapun usaha yang kita lakukan akan sangat besar manfaatnya bagi terwujudnya bumi yang layak huni bagi generasi yang akan datang.

Upaya pelestarian lingkungan mutlak harus dilaksanakan sebagai upaya pelestarian komponen-komponen lingkungan hidup beserta fungsi yang melekat dan interaksi yang terjadi antar komponen tersebut. Karena adanya perbedaan fungsi antara komponen dan pemanfaatan dalam pembangunan, maka pelestarian tidak dipahami sebagai pemanfaatan yang dibatasi, namun pelestarian hendaknya dipahami sebagai pemanfaatan yang memperhatikan fungsi masingmasing komponen dan interaksi antar komponen lingkungan hidup yang pada akhirnya diharapkan pelestarian lingkungan hidup akan memberikan jaminan eksistensi masing-masing komponen lingkungan hidup.

Upaya pemerintah untuk mewujudkan kehidupan yang adil dan makmur bagi rakyatnya tanpa harus menimbulkan kerusakan lingkungan ditindak lanjuti dengan menyusun program pembangunan 
berwawasan

Pembangunan

lingkungan.

berwawasan

lingkungan adalah usaha untuk meningkatkan kualitas manusia secara bertahap dengan memperhatikan faktor lingkungan.

Pembangunan

berwawasan lingkungan dikenal dengan pembangunan berkelanjutan dengan konsep yang merupakan hasil dari KTT Bumi di Rio de Jeiniro tahun 1992, yang memuat

2 gagasan penting, yaitu:

1. Gagasan kebutuhan, khususnya kebutuhan pokok manusia untuk menopang hidup.

2. Gagasan keterbatasan, yaitu keterbatasan kemampuan lingkungan untuk memenuhi kebutuhan baik masa sekarang maupun masa yang akan datang.

Selain upaya yang telah dilakukan oleh pemerintah, pelibatan masyarakat dalam upaya pelestarian lingkungan merupakan unsur yang sangat dominan, karena mereka yang akan menentukan berhasil tidaknya upaya pelestarian tersebut. Kesadaran masyarakat akan pentingnya menjaga lingkungan hidup dirasakan masih kurang, masih banyak terlihat perilaku-perilaku yang justru malah merusak lingkungan hidup. Masalah lingkungan merupakan masalah yang timbul sebagai akibat dari ulah manusia itu sendiri, maka penanggulangannya juga ditentukan oleh perilaku hidup manusia yang ramah lingkungan.

Untuk menciptakan manusia yang ramah lingkungan, diperlukan peran pendidikan khususnya sekolah, sebab di sekolah terdapat banyak sekali generasi muda yang akan menjadi pewaris di bumi ini yang dapat ditempa kesadarannya untuk mencintai lingkungan. Salah satu cara adalah dengan menciptakan sekolah ramah lingkungan melalui gerakan "Go Green School" menuju "Go Green at Home" dan "Go Green Indonesia ".

Kegiatan penghijauan sekolah adalah kegiatan yang sangat penting dilakukan dalam menangani krisis lingkungan dan pemanasan global yang sedang terjadi saat ini. Penghijauan dalam arti luas adalah segala daya untuk memulihkan, memelihara dan 
meningkatkan kondisi alam agar dapat terus berproduksi dan berfungsi secara optimal, baik sebagai pengatur tata air atau pelindung lingkungan. Namun program ini, sampai sekarang belum tersentuh bahkan terabaikan dikarenakan ada anggapan bahwa masalah kebersihan, kesehatan lingkungan dan penghijauan adalah urusan pihak lain dan atau petugas khusus, umumnya lembaga pendidikan lebih mengutamakan proses pembelajaran ranah kognitif dan ranah lainnya dan sehingga terkesan kurang bertanggung jawab akan permasalahan lingkungan, padahal unsur-unsur sekolah dapat diberdayakan secara optimal dan menggunakan prinsip kerjasama antara pihakpihak terkait, hal ini harus ditekankan karena lembaga pendidikan merupakan tempat untuk mengantarkan anak menuju kedewasaan.

Kegiatan penghijauan mempunyai banyak peran dan fungsi, yaitu :

1. Sebagai paru-paru lingkungan yang sangat diperlukan makhluk hidup untuk bernafas sebagai pengatur lingkungan yang dapat memberikan kesejukan, kenyamanan serta kesegaran dilingkungan sekitar.

2. Sebagai pencipta lingkungan hidup yang dapat melestarikan kehidupan keindahan di lingkungan hidup tersebut.

3. Sebagai penyeimbangan alam yang dapat membentuk tempat hidup alam untuk satwa yang hidup di sekitar lingkungan tersebut.

4. Sebagai perlindungan yang dapat memberikan kondisi fisik alami di sekitar lingkungan tersebut.

5. Sebagai keindahan yang dapat dijadikan panorama hidup

6. Sebagai kesehatan yang dapat memberikan fisik, jasmani, maupun rohani yang sehat bagi makhluk hidup yang ada disekitarnya.

(Faris Tri Ardannny di.05.14. EmailBlog)

Dengan dibiasakan gerakan mencintai kebersihan dan mencintai lingkungan di sekolah, diharapkan tertanam dan muncul 
kesadaran yang kuat, untuk selalu hidup bersih yang kemudian terbawa dan diaplikasikan dalam kehidupan peserta didik di masyarakat, dimana mereka tinggal, sehingga diharapkan bisa membawa perubahan pada cara pandang dan kesadaran masyarakat akan pentingnya menjaga dan melestarikan lingkungan, serta semakin aktif dalam upaya-upaya pelestarian lingkungan sebagai bentuk rasa nasionalisme warga negara khususnya rasa cinta terhadap tanah airnya.

\section{B. Tinjauan Pustaka}

\section{Gerakan Go Green School}

Secara harfiah Green

School berarti sekolah hijau, namun sebenarnya memiliki makna yang lebih luas. Green School bukan hanya tampilan fisik saja yang hijau atau rindang, tetapi wujud sekolah yang memiliki program dan aktifitas pendidikan mengarah kepada kesadaran dan kearifan terhadap lingkungan hidup.

"Sekolah Hijau", yaitu sekolah yang memiliki komitmen

$\begin{array}{lr}\text { dan secara } & \text { sistematis } \\ \text { mengembangkan } & \text { program- } \\ \text { program } & \text { untuk }\end{array}$

menginternalisasikan nilai-nilai lingkungan ke dalam seluruh aktifitas sekolah. Tampilan fisik sekolah ditata secara ekologis sehingga menjadi wahana pembelajaran bagi seluruh warga sekolah untuk berperilaku arif dan berperilaku ramah lingkungan. Program pendidikan dikemas secara partisipatif penuh, percaya pada kekuatan kelompok, mengaktifkan dan menyeimbangkan Feeling, Acting dan Thinking, sehingga tiap individu bisa merasakan nilai keagungan inisiasinya.

Munculnya gerakan Green School ini dilatar belakangi oleh kerusakan lingkungan yang cenderung meningkat akibat bertambahnya penduduk dan upaya-upaya pemanfaatan sumber daya alam tanpa disertai upaya pelestarian fungsi lingkungan. Akhirnya terjadi ketidakseimbangan di alam, akibat ulah manusia yang tidak bertanggung jawab tersebut. 
Isu-isu lingkungan yang bersifat global seperti perubahan iklim berkaitan dengan naiknya suhu udara permukaan bumi, peningkatan $\mathrm{CO}_{2}$ dan berkurangnya luas hutan dunia. Pertumbuhan penduduk dan pengambilan sumber daya alam yang jauh melampaui daya dukungnya merupakan salah satu penyebabnya. Isu-isu tersebut berkembang menjadi permasalahan lingkungan yang serius. Pencemaran udara, sampah, kelangkaan air bersih, kerusakkan lahan dan hutan, longsor, banjir dan kekeringan, merupakan masalah yang sudah menjadi bagian dari kehidupan masyarakat dewasa ini.

\section{Penanganan masalah} lingkungan telah dilakukan berbagai kalangan, tingkat lokal, pemerintah maupun masyarakat berupaya dengan berbagai pendekatan. Tapi upaya-upaya tersebut belum menampakkan hasil yang nyata, karena :

1. Rendahnya partisipasi masyarakat untuk berperan dalam Pendidikan Lingkungan Hidup.Hal inikarena kurangnya pemahaman, rendahnyatingkat kemampuan atau keterampilan, serta rendahnya komitmen masyarakat dalam menyelesaikan masalah;

2. Pemahaman pelaku pendidikan terhadap Pendidikan Lingkungan Hidup masih terbatas, masih ada anggapan bahwa Pendidikan Lingkungan Hidup tidak penting;

3. Materi dan metode pelaksanaan Pendidikan Lingkungan Hidup belum memadai dan kurang aplikatif, siswa lebih banyak diberikan teori, masih kurangnya aksi nyata, sehingga pemahaman siswa tidak utuh;

4. Masih kurangnya perhatian terhadap sarana dan prasarana Pendidikan Lingkungan Hidup;

5. Kurangnya alokasi anggaran untuk Pendidikan Lingkungan dari pemerintah, sehingga pelaksanaan kurang optimalnya pelaksanaan Pendidikan Lingkungan;

6. Lemahnya koordinasi antar instansi terkait dan para pelaku 


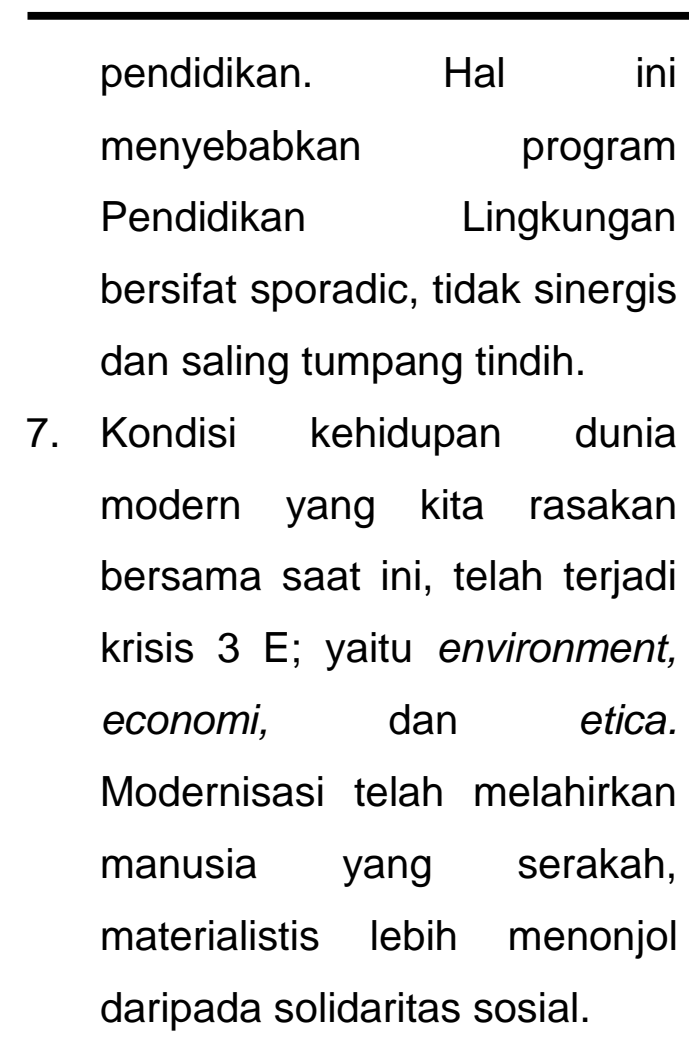

Green School lebih bermakna pada pembentukkan sikap anak didik dan warga sekolah terhadap lingkungan, yang tercermin dalam kehidupan se hari-hari di sekolah. Hal ini diwujudkan dalam sikap dan perilaku sehari-hari, baik di sekolah, rumah atau di lingkungan tempat tinggalnya. Termasuk di dalamnya program "Greening The Curriculum”, kurikulum hijau, artinya kurikulum yang memperhatikan aspek-aspek lingkungan dalam bahasannya serta mengintegrasikan materi lingkungan ke dalam pembelajarannya, sesuai dengan topik bahasannya.

Pengembangan program Green School menurut versi "KEHATI"

(http://dikihafid.wordpress.com), dilakukan melalui lima kegiatan utama meliputi :

1. Pengembangan kurikulum berwawasan lingkungan

2. Pengembangan pendidikan berbasis komunitas

3. Peningkatan kualitas kawasan sekolah dan lingkungan sekitarnya

4. Pengembangan sistem pendukung yang ramah lingkungan

5. Pengembangan manajemen sekolah berwawasan lingkungan

\section{Nasionalisme}

Nasionalisme adalah suatu gerakan social, atau aliran rohaniah yang mempersatukan rakyat ke dalam " state" yang membangkitkan masa ke dalam keadaan politik dan sosial yang aktif. Dengan nasionalisme dapat dipandang sebagai landasan ideal dari setiap negara. Nasionalisme 
sebagai manifestasi kesadaran nasional yang mengandung citacita, merupakan ilham yang mendorong dan merancang suatu bangsa. F. Isjwara (1989:130) menyebutkan empat macam citacita nasionalisme, yaitu:

1. Perjuangan untuk mewujudkan persatuan nasional yang meliputi bidang politik, ekonomi, social, keagamaan, kebudayaan, dan persekutuan serta adanya solidaritas.

2. Perjuangan untuk mewujudkan kebebasan nasional yang meliputi kebebasan dari kekuatan-kekuatan intern yang tidak bersifat nasional atau yang hendak mengenyampingkan bangsa dan Negara.

3. Perjuangan untuk mewujudkan kesendirian, pembedaan, individualitas, keaslian dan keistimewaan.

4. Perjuangan untuk mewujudkan pembedaan di antara bangsabangsa yang meliputi perjuangan untuk memperoleh kehormatan, kewibaan, gengsi dan pengaruh.
Dari uraian di atas tampak bahwa Negara dan bangsa sebagai kelompok manusia yang :

1. Memiliki cita-cita bersama yang mengikat warga Negara menjadi satu kesatuan.

2. Memiliki adat, budaya dan kebiasaan yang sama sebagai akibat pengalaman hidup bersama

3. Memiliki sejarah hidup sehingga tercipta rasa senasib sepenanggungan.

4. Menempati suatu wilayah tertentu yang merupakan kesatuan wilayah.

5. Terorganisir dalam suatu pemerintah yang berdaulat sehingga mereka terikat dalam suatu masyarakat hukum.

Nasionalisme selalu mengikat secara bersama orangorang yang terlibat dalam suatu kesatuan emosi tersebut. Kesatuan emosi tersebut menumbuhkan rasa perasaan "bersatu" dalam sebuah konsep kebangsaan tertentu. Nasionalisme secara luas dapat dikatakan menyatakan patriotisme (patria = cinta tanah air) yang merupakan prinsip moral dan 
politik yang mengandung kecintaan terhadap tanah air, kebangsaan emosional terhadap sejarah dan ketersediaan diri untuk membela kepentingan-kepentingan bangsa.

Nasionalisme juga dapat dihayati sebagai solidaritas hidup warga yang terhimpun dalam sebuah negara-bangsa (nationstate). Solidaritas itu meliputi solidaritas warga yang ada di dalam negara-bangsa tersebut dalam mengatasi berbagai masa dan solidaritas dalam bertindak/berperilaku, yang ditujukan untuk kepentingan bersama dalam mewujudkan citacita negara-bangsa.

Pada prinsipnya

nasionalisme merupakan suatu konsep dari persatuan, yang oleh Ernest Renan disebut sebagai " Le desire d'etre ensemble". Konsep dari persatuan tersebut terdapat dalam suatu kelompok manusia yang mendiami wilayah tertentu dan dinamakan suatu bangsa. Bangsa dalam arti sebuah kontruksi yang dihasilkan dari perjuangan-perjuangan dari orangorang yang mempunyai kehendak untuk bersatu untuk menentukan nasib sendiri, ingin membentuk sebuah bangsa dalam suatu negara merdeka dan berdaulat. Dengan demikian nasionalisme bukan saja lebin dulu lahir dari bangsa, namun juga merupakan "pencipta bangsa", bukan bangsa yang melahirkan nasionalisme.

\section{Metode Penelitian}

\section{Pendekatan Penelitian}

Penelitian ini menggunakan pendekatan kualitatif, yakni kajian yang dalam pengolahan data, sejak mereduksi, menyajikan dan memverifikasi serta menyimpulkan data, tidak menggunakan perhitungan-perhitungan secara matematis dan statistik, melainkan lebih menekankan pada kajian interpretatif. Berkait dengan penelitian kualitatif ini Creswell (1998:15) mengemukakan bahwa : Qualitative research is an inquiry process of understanding based on distinct methodological traditions of inquiry that explore a social or human problem. The researcher builds a complex, holistic picture, analyses words, reports detailed views of informants, and conducts the study in a natural setting. 


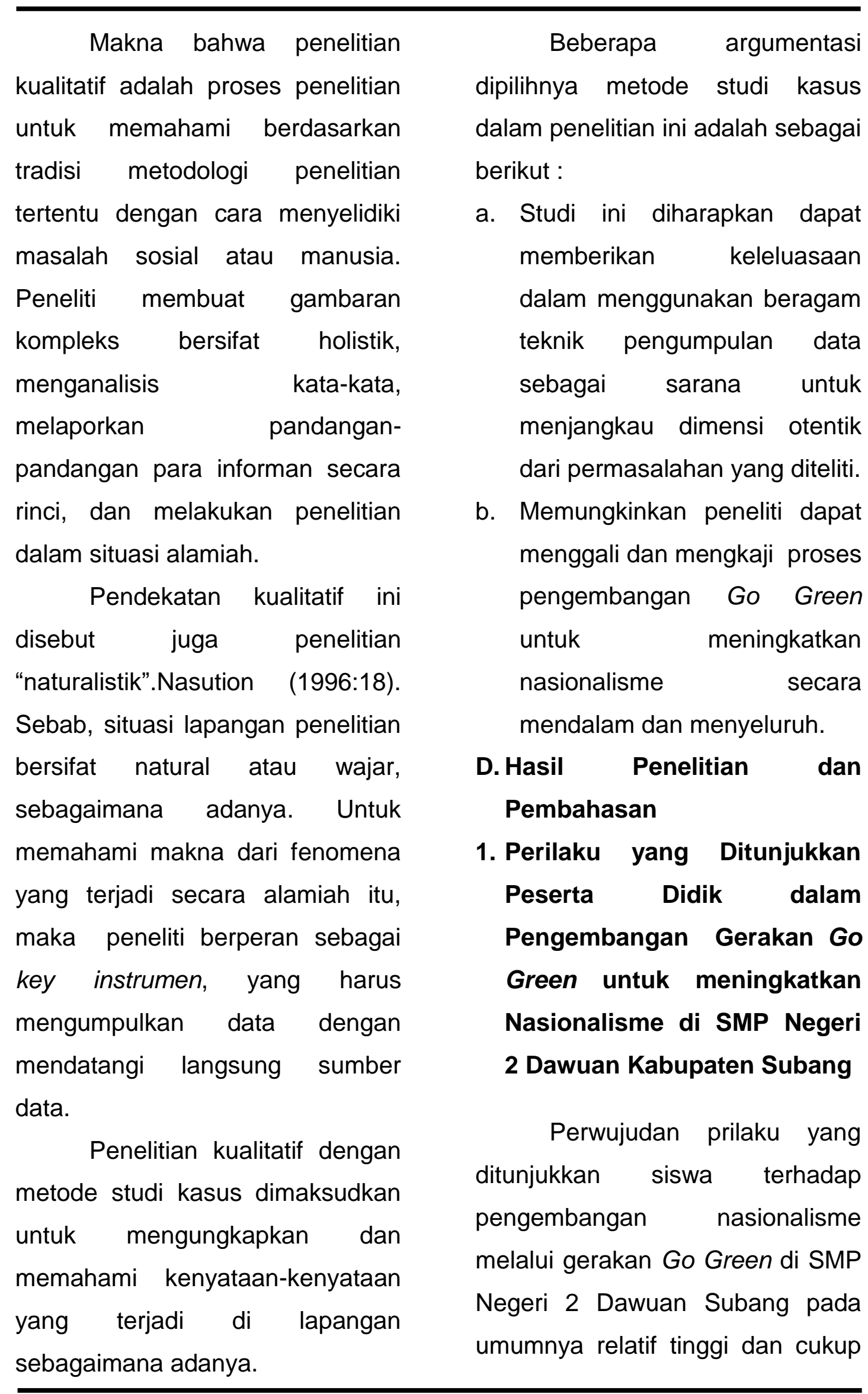


memuaskan. Dalam kaitan itu ditemukan sejumlah prilaku yang ditunjukkan oleh peserta didik di dalam kelas maupun di luar kelas.

Deskripsi hasil penelitian memperlihatkan bahwa perwujudan prilaku Go Green di dalam kelas diantaranya adalah pemberian materi pembelajaran lingkungan hidup, di dalam kelas ada program $5 \mathrm{R}$ sebagai pedoman di sekolah., mengepel lantai kelas, memasang slogan tentang kebersihan, membuat rak sepatu, dan mengecat kelas sendiri, penanaman di halaman kelas, pengecatan, pembuatan pot dan tong sampah serta setiap siswa diharuskan membawa 10 polibag tanaman.

Sedangkan diluar kelas adalah piket lingkungan yang dilaksanakan perhari, yang bertugas menjaga kavling yang sudah ditugaskan dan bertanggung jawab dengan seluruh kebersihannya. Tugasnya menjaga lingkungan publik (di luar kelas masing-masing) agar tetap bersih. Lingkungan publik yang dimaksud adalah jalan utama, daerah antara kelas. Petugas adalah tiap kelas yang digilir dan semuanya bertanggung jawab terhadap lingkungannya Karena wilayahnya cukup luas maka pembagian wilayah di SMP Negeri 2 Dawuan Subang di bagi menjadi 3 kavling, jadi tiap hari ada satu peleton yang berjumlah antara 20 - 40 siswa, targetnya adalah menjaga kebersihan kavlingnya. Selain dinas kebersihan ada juga dinas keamanan dan ketertiban, jadi ada yang bertugas membersihkan, ada juga yang dinas jaga di pos yang telah ditentukan dan mulai berjaga dari jam 16.00 sampai jam 22.00 WIB dan didampingi oleh seorang perwira (guru). Kegiatan lainnya adalah bakti lingkungan di daerah tertentu, penanaman 1000 pohon yang bekerja sama dengan dinas kehutanan.

Gerakan Go Green merupakan salah satu cara upaya untuk meningkatkan nasionalisme, rasa cinta tanah air dengan cara minimal mencintai bumi dan lingkungannya agar tetap lestari, jadi dengan Go Green anak sadar akan diri dan lingkungannya. Dengan dimulai dari hal-hal yang 
kecil dan mudah misalnya membuang sampah pada tempatnya atau memilah sampah organik dan non organik, memotong rumput, membersihkan tong sampah, mengangkut sampah yang ada di tong masingmasing kelas dan membawanya ke tempat pembuangan akhir.

Sebagai langkah-langkah yang diambil dalam penerapan gerakan Go Green ini guru harus memberi pemahaman bahwa dengan mencintai lingkungan dia sama juga mencintai bangsa dan negaranya. Gerakan Go Green lingkupnya kecil, dari sekolah baru meningkat ke lingkup yang lebih besar. Setelah itu adalah penyadaran, namun untuk kearah itu belum bisa sehingga untuk mencapai target dan tujuan maka dilakukan melalui pemaksaan yakni dengan membuat program dan di berlakukan pada peserta didik. Dengan konsekuensi ketika dia mau masuk dan sekolah di SMK 2 Subang harus mentaati dan melaksanakan aturan yang berlaku .

Seandainya ada peserta didik yang melanggar peraturan maka dibuat sangsi. Penerapan sangsi bagi mereka yang membuang sampah sembarangan , dikenakan sangsi yang berupa: (a) nilai yang rendah pada monitoring dan evaluasi, (b). mengawasi dan mencari 6 siswa yang melakukan tindakan serupa,(c) bila kita membuang satu gelas aqua, maka kita diharuskan mencari 100 gelas aqua yang ada di sekolah.

Pemberian sangsi tersebut diberikan agar peserta didik mempunyai kesadaran akan pentingnya mencintai lingkungan dan membudayakan hidup bersih dilingkungan sekolah.

Dalam konteks membangun sekolah berwawasan lingkungan, pemberian sanksi atas pelanggaran peserta didik, khususnya dalam pandangan humanistik, sanksi sebaiknya tidak sering dilakukan. Sanksi adalah langkah terakhir apabila cara-cara pengendalian lainnya dipandang tidak ampuh, jika kita terpaksa menerapkan sanksi, maka hendaknya dikombinasikan dengan pemberian reward dan reinforcement. 


Gerakan Go Green
merupakan suatu upaya untuk
meningkatkan rasa nasionalisme
peserta didik di SMP Negeri 2
Dawuan Kabupaten Subang.
Dengan cara memberikan
pemahaman, penyadaran dan
pemaksaan agar peserta didik
mempunyai kesadaran akan
pentingnya mencintai lingkungan
dan membudayakan hidup bersih
dilingkungan sekolah, dan jika
terpaksa menerapkan sanksi yang
dikombinasikan dengan pemberian
reward dan reinforcement.

\section{Hambatan Implementasi} Gerakan Go Green di SMP Negeri 2 Dawuan Kabupaten Subang.

Sebagaimana terungkap
dari deskripsi hasil penelitian
ternyata dalam pelaksanaan
gerakan Go Green masih
menemui sejumlah hambatan
diantaranya adalah:

a. Adanya perbedaan sikap dan persepsi dari para guru. Perbedaan persepsi ini diakibatkan oleh tingkat kepedulian yang berbeda dari para guru.
Untuk mengatasi masalah tersebut harus ada evaluasi dari gerakan yang sudah dilaksanakan sebab waktu pencanangannya juga dilaksanakan bersama maka untuk mengatasi hambatan juga harus dilaksanakan evaluasi bersama. Cara lain adalah menunjukan keteladanan sehingga siswa dapat melihat contoh-contoh gerakan Go Green dari gurunya.

b. Hal pengelolaan manusianya, dimana mereka mempunyai persepsinya masing-masing karena memakai standar sendiri.

Dengan kondisi seperti itu maka salah satu cara pemecahannya adalah harus ada standar baku dan tingkatkan rasa kepedulian. Seandainya masih tidak peduli ada reward dan punishment, walau tetap harus ada pemaksaan.

c. Komitmen dan sumberdaya manusia yang masih rendah serta sarana dan prasarana. Masalah komitmen dan sumberdaya ini diakibatkan oleh 
kurangnya kesadaran dan

keterbatasan dari individunya.

Untuk mengatasi hal tersebut harus ada sosialisasi, evaluasi dan refresing.

d. Sarana prasarana yang belum memadai dan kurangnya kesadaran anak untuk memelihara kebersihan lingkungan.

Untuk mengatasinya terkadang siswa disuruh membawa peralatan kebersihan sendiri untuk membersihkan lingkungan sekolah dan untuk mengatasi hal tersebut anak dipanggil, ditanya dan diberikan pemahaman bahwa menjaga kebersihan merupakan salah satu indikator penilaian, dan seandainya siswa tidak melakukan hal tersebut berarti dia tidak mendapatkan nilai.

e. Kurangnya kesadaran siswa dalam menyukseskan gerakan Go Green, hal ini diakibatkan oleh kebiasaan siswa. Untuk masalah sarana kendala terdapat pada tempat pemilahan sampah organik dan nonorganik masih sempit, jadi kurang leluasa.
Untuk mengatasi kendala tersebut adalah dengan adanya pemaksaan atau penekanan sampai mereka melaksanakannya.

f. Kesadaran yang masih kurang dari siswa dalam arti siswa mau melaksanakan hal tersebut bila ada perintah atau instruksi dari guru. Hal tersebut dikarenakan diri siswa tersebut lebih mementingkan hal-hal bersifat pribadi daripada mementingkan perintah gurunya.

Untuk mengatasinya bisa dilakukan dengan cara saling saling mengingatkan antar teman, memberi nasehat dan adanya pemaksaan dengan harapan dia lebih melaksanakan pekerjaan sesuai dengan tanggung jawabnya.

g. Minat dari siswanya, banyak siswa yang kurang peduli yang disebabkan oleh kesadaran diri yang kurang.

Untuk mengatasi masalah terrsebut harus ada pemaksaan untuk melakukan, setelah biasa nanti akan terbiasa dan akhirnya menjadi budaya. 


\begin{abstract}
Hambatan implementasi gerakan Go Green di SMP Negeri 2 Dawuan Kabupaten Subang, dapat dirumuskan kesimpulan sementara sebagai berikut: Hambatan serta upaya pemecahannya dalam pelaksanaan gerakan Go Green adalah dari dalam diri manusianya bisa persepsi, minat, sikap, komitmen dan sarana prasarana yang bisa diatasi melalui adanya standar baku, sosialisasi, menunjukkan keteladanan, memberi nasehat, pemahaman, reward and punishment dan pemaksaan/ penekanan.
\end{abstract}

1. Prospek Implementasi dan harapan Gerakan Go Green baik untuk Sekolah, Masyarakat dan Perusahaan.

\section{a. Sekolah}

Program Green school merupakan bagian tak terpisahkan dari keseluruhan program pengembangan sekolah, oleh sebab itu program Green School akan terintegrasi ke dalam program pengembangan sekolah.

$$
\text { Pengembangan kurikulum }
$$
berwawasan lingkungan dan pendidikan berbasis komunitas terwadahi dalam program kurikuler dan ekstrakurikuler. Sedangkan pengembangan kawasan sekolah dan pengembangan sistem pendukung ramah lingkungan termasuk dalam program pengelolaan lingkungan fisik/fasilitas.Selanjutnya

pengembangan lingkungan social/lingkungan kerja merupakan bagian dari pengembangan manajemen sekolah.

Prospek gerakan Go Green cukup bagus serta rencana ke depannya adalah berharap SMP Negeri 2 Dawuan Subang menjadi sekolah agrowisata dengan pola-pola yang dikembangkan untuk penataan lingkungan dan pepohonan sehingga menjadi lebih nyaman. Sejak dicanangkannya Go Green banyak sekali aktifitas dan kreatifitas yang muncul dari guru misalnya, setelah melihat banyak sampah muncul usul untuk mengelola limbah tahun 2010, terus ada tempat pemisahan sampah organik dan non organik, muncul usulan adanya "smoking area" bagi guru, membangun 
kamar mandi, penampungan limbah dan membangun pabrik tahu.

Sedangkan kreatifitas dar siswa diantaranya membuat potpot bunga, pengecatan kelas sendiri, membuat tulisan-tulisan yang berisikan ajakan hidup bersih, taman di depan kelas dan membuat tempat sampah kreatif.

\section{b. Masyarakat}

Pembinaan sikap dan karakter bersih, rapi, tanggung jawab merupakan modal utama untuk dapat bekerja dengan baik. Faktor-faktor inilah yang membuat masyarakat menyekolahkan anaknya ke SMK karena dilihat dari kedisiplinannya, Masyarakat dan orangtua berharap ada perubahan karakter dari anaknya, dengan dibiasakan bersikap bersih dan mencintai lingkungan serta pengetahuan yang telah mereka dapatkan di sekolah, akan berguna dalam kehidupan di lingkungan masyarakatnya.

$$
\text { Minat orangtua dan }
$$
masyarakat menyekolahkan anaknya karena mengharapkan anaknya berkarakter baik, mencintai lingkungan, disiplin serta berharap dapat bekerja lebih cepat. Perusahaan pasti tertarik kepada karyawan yang disiplin, cinta kebersihan dan berkarakter yang sudah dipupuk, dibiasakan pada masa pembinaan dan kebiasaan-kebiasaan yang dilakukan sebagai perwujudan pelaksanaan Go Green.

\section{E. Kesimpulan}

Kesimpulan umum dalam penelitian ini adalah bahwa pengembangan gerakan Go Green dalam meningkatkan nasionalisme menjadi kebutuhan bagi setiap sekolah untuk menciptakan kondisi yang baik dan nyaman bagi sekolah untuk menjadi tempat pembelajaran dan penyadaran warga sekolah akan pentingnya menjaga, mengelola dan memanfaatkan lingkungan, sehingga di kemudian hari warga sekolah tersebut dapat turut bertanggung jawab dalam upayaupaya penyelamatan lingkungan hidup sebagai bentuk rasa cinta pada tanah air.

1. Perilaku yang ditunjukkan peserta didik terhadap 


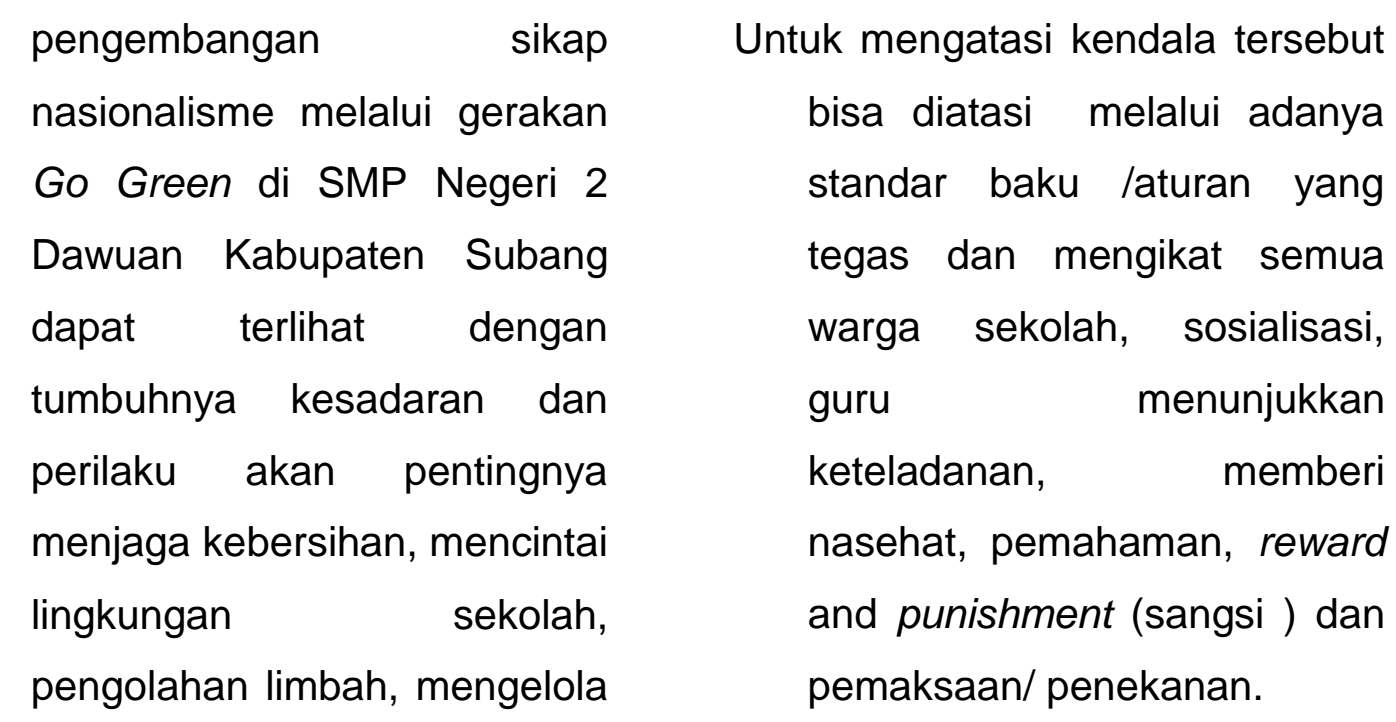
serta memanfaatkan alam, yang selain muncul dari dalam pribadi peserta didik juga karena diberlakukan sistem ketarunaan yang bersifat militer dengan aturan yang tegas mendorong peserta didik untuk menunjukkan perilaku yang dilandasi oleh semangat nasionalisme dalam perwujudan budaya Go Green.

2. Hambatan dan kendala dalam pelaksanaan gerakan Go Green adalah dari dalam diri pesrta didik sendiri yaitu pada kesadaran yang kurang yang diakibatkan oleh persepsi yang berbeda, minat yang kurang, sikap ketidak pedulian, komitmen yang lemah.

3. Prospek implementasi dan harapan gerakan Go Green baik untuk sekolah,dan masyarakat, bahwa proses pelaksanaan gerakan Go Green di SMP Negeri 2 Dawuan Subang sangat bagus dan harus terus di dikembangkan sesuai dengan kebijakan sistem mutu 9001:2008 dan sistem lingkungan 14001:2004, serta melaksanakan programprogram yang menginternalisasi nilai-nilai lingkungan ke dalam seluruh aktifitas sekolah disertai dengan peningkatan kompetensi yang mampu bersaing, pembentukan karakter peserta didik yang mempunyai sikap dan 
kepribadian kuat, serta mutu lulusan yang sangat siap memasuki dunia kerja/dunia industri sehingga mampu memberikan prospek yang cerah bagi sekolah, masyarakat serta perkembangan program sekolah yang berbasis lingkungan.

\section{DAFTAR PUSTAKA}

Abdullah, Taufik

(2001)

Nasionalisme \& Sejarah, Bandung : Satya Historika

Anderson, Benedict (2008) Imagined Communities (Komunitas-komunitas

Terbayang). Yogyakarta : Kerjasama Insist dan Pustaka Pelajar.

Azra, A. (2002). Paradigma Baru Pendidikan Nasional : Rekonsiliasi dan Demokratisasi. Jakarta : PT Kompas Media Nusantara.

Budiardjo, M. (1989). Dasar-dasar IImu Politik. Jakarta : PT Gramedia.

Budimansyah, D. dan Suryadi, K. (2008). PKn dan Masyarakat
Multikultural. Bandung : Prodi PKn SPs UPI.

Branson, M.S. (1998). The Role of Civic Education. Calabasas: CCE

Cogan, J.J. dan Derricott, R. (1998). Citizenship For 21st Century ; An International Perspektive on Education. London : Kogan Page.

Creswell, J.W. (1994). Research Design Qualitative \& Quantitative Approach. London: Publications

Darmodihardjo, Darji. (1986). Nilai, Norma, dan Moral. dalam Penghayatan dan Pengalaman Pancasila. Jakarta. Aries Lima.

Diamond Larry, Marc F Plattner (1994). Nationalism, Ethnic Conflict, and Democracy. Diterjemahkan : Somardi, Bandung : ITB Press

Djahiri, A.K. (2006). "Esensi Pendidikan Nilai Moral dan PKn di Era Globalisasi”, dalam Pendidikan Nilai Moral dalam Dimensi Pendidikan Kewarganegaraan. Bandung : Lab. PKn FPIPS UPI. 
Didaktik : Jurnal Pendidikan, ISSN : 2477-5673, E-ISSN : 2614-722X

Sekolah Tinggi Keguruan dan IImu Pendidikan Subang Volume V Nomor 1, Juni 2019

Fachrudin, F. (2006). Agama dan

Pendidikan Demokrasi :

Pengalaman Muhammadiyah dan NU. Jakarta : PT Alvabet. Gadjong,

A.A.

(2007).

Pemerintahan Daerah :

Kajian Politik dan Hukum.

Bogor : Penerbit Ghalia Indonesia.

Gaffar, A. (2006). Politik Indonesia

: Transisi Menuju Demokrasi.

Yogyakarta : Pustaka Pelajar.

Giddens, A (1990) The

Consequences Modernity,

Stanford, California University

Press

Kartodirdjo, Sartono (1999)

Pendekatan IImu Sosial dalam Metodologi Sejarah.

Jakarta: Gramedia

Koentjaraningrat. (1990). Sejarah

Teori Antropologi. Jakarta:

Universitas Indonesia.

Kohn, Hans (1984) Nasionalisme

Arti dan Sejarahnya , Jakarta:

Erlangga bekerjasama

dengan PT Pembangunan

Lincoln, Y.S. dan Guba, E.G.

(1985). Naturalistic Inquiry.

Baverly Hills: Sage

Publications.
Miles, M.B. dan Huberman, A.M. (2007). Analisis Data Kualitatif: Buku Sumber Tentang Metode-Metode Baru. Jakarta: Universitas Indonesia Press

Moleong, J.L. (2008). Metodologi

Penelitian Kualitatif. Bandung : PT Remaja Rosdakarya.

Muchtar, S.A. (2001). Pendidikan dan Masalah Sosial Budaya. Bandung : Gelar Pustaka Mandiri.

Muljana, Slamet (2008).

Kesadaran Nasional dari Kolonialisme sampai

Kemerdekaan. Yogyakarta:

PT LKiS Pelangi Aksara.

Nazir, M. (2007). Metode Penelitian. Jakarta : Ghalia Indonesia.

Nasution, S. (1996). Metode Penelitian Naturalistik

Kualitatif. Bandung: Tarsito.

Poespowardojo, S. (1999) Menuju Integrasi Bangsa Indonesia Masa Depan. Jakarta: LP3ES Rahardjo, M.D. (1999). Masyarakat Madani : Agama, Kelas Menengah dan Perubahan Sosial. Jakarta : LP3ES. 
Renan, Ernest. (1990) " What is A Nation ?" dalam Nation and Narration. Di edit oleh Homi

Bhabha, London: Routledge Sanusi,

A.

(2007).

"Memberdayakan Masyarakat dalam Pelaksanaan 10 Pilar

Demokrasi", dalam

Pendidikan Nilai Moral dalam

Dimensi Pendidikan

Kewarganegaraan. Bandung : Lab. PMPKn FPIPS UPI.

Sapriya dan Winataputra, U.S. (2004).

Pendidikan

Kewarganegaraan : Model

Pengembangan Materi dan

Pembelajaran. Bandung :

Lab. PKn FPIPS UPI.

Soekanto, S. (1990). Sosiologi :

Suatu Pengantar. Jakarta :

CV Rajawali.

Suseno, F.M. (1995). Mencari

Sosok Demokrasi. Jakarta : Gramedia

Suyatno. (2008). Menjelahi

Demokrasi. Bandung : PT Humaniora.

Tilaar, H.A.R. (2002). Pendidikan,

Kebudayaan dan Masyarakat Madani Indonesia. Bandung :

PT Rosda Karya.
Ubaidillah, A. dan Rozak, A. (2008).

Pendidikan

Kewarganegaraan (Civic

Education). Jakarta : ICCE

UIN Syarif Hidayatullah.

Wasistiono, S. dan Wiyoso, Y. (2009). Meningkatkan Kinerja Dewan Perwakilan Rakyat Daerah. Bandung : PT Fokusmedia.

Winataputra, U.S. dan

Budimansyah, D. (2007).

Civic Education : Konteks, Landasan, Bahan Ajar dan Kultur Kelas. Bandung : Prodi PKn SPS UPI.

Yin, R.K.,(2009). Studi Kasus: Desain \& Metode. Jakarta : PT Raja Grafindo Persada.

\section{Sumber Jurnal :}

Almond, G. (1996). The Civic Culture: Prehistory, Retrospect and Prospect, Center for the Study of Democracy, UC Irvine: Research Paper Series in Empirical Democratic Theory, No. 1.

Bahmueller, C.F. (1997). A Frame for Teaching Democratic Citizenship : An International Project. In The International 
Didaktik : Jurnal Pendidikan, ISSN : 2477-5673, E-ISSN : 2614-722X

Sekolah Tinggi Keguruan dan IImu Pendidikan Subang Volume V Nomor 1, Juni 2019

Journal of Social Education, 12, (2), 216-221.

Kerr, D. (1999). Citizenship Education : An International Comparison. London:

National Fondation For Education Research-NFER.

Komalasari, K. dan Budimansyah, D. (2008). Pengaruh Pembelajaran $\quad P K n$ Kontekstual terhadap

Kompetensi

Kewarganegaraan SMP. Acta Civicus. 2, (1), 76-97.

Suryadi, A. (2003). Tantangan

Pendidikan di Era

Desentralisasi. Buletin Pusat

Perbukuan Depdiknas. 2, 4-6.

Winataputra, U.S. (2008).

Multikulturalisme Bhinneka

Tunggal lka dalam Perspektif

Pendidikan

Kewarganegaraan sebagai

Wahana Pembangunan

Karakter Bangsa Indonesia.

Acta Civicus. 2, (1), 1-16.

Tesis, Desertasi, Pengukuhan

Guru Besar dan Penelitian :

Suhartono, et al. (2008). Tingkat

Kesadaran Politik Pemilih

Pemula dalam Pilkada: Suatu

Refleksi

School-Based
Democracy Education Model (Studi Kasus Pilkada banten dan Jawa Barat). Hasil Penelitian pada SPs UPI.

Winataputra, U.S. (2001). Jatidiri Pendidikan

Kewarganegaraan sebagai Wahana Sistemik Pendidikan Demokrasi. Ringkasan Desertasi Doktor pada FPS UPI Bandung : tidak diterbitkan.

Zamroni. (2002). Demokrasi dan Pendidikan Dalam Transisi : Perlunya Reorientasi Pengajaran IImu-IImu Sosial di Sekolah Menengah. Pidato Pengukuhan Guru Besar pada FIS UNY Yogyakarta : tidak diterbitkan

\section{Sumber Makalah/Artikel :}

Madjid, Nurcholis (2000). "AsasAsas Pluralisme dan Toleransi dalam Masyarakat Madani". Makalah lokakarya Islam dan Pengembangan Civil Society di Indonesia, kerja sama IRIS BandungPPIM Jakarta-The Asia Foundation. 
Didaktik : Jurnal Pendidikan, ISSN : 2477-5673, E-ISSN : 2614-722X

Sekolah Tinggi Keguruan dan IImu Pendidikan Subang Volume V Nomor 1, Juni 2019

Winataputra, U.S. (2005).

"Pendidikan

Kewarganegaraan Untuk

Membangun Masyarakat

Demokratis Berkeadaban

: Tinjauan Filosofis-

Pedagogis". Makalah

pada Seminar dan

Lokakarya Dosen PKn
PTN dan PTS, Medan, 22

September.

Sumber Perundang-Undangan :

Undang-Undang Dasar 1945 Hasil

Amandemen

Undang-Undang Nomor 20 Tahun 2003 tentang Sistem

Pendidikan Nasional RI 